\title{
HOWARD LOVES POLLY
}

\author{
In search of something real.
}

\section{BY MARTIN HAYES}

$\mathrm{H}$ oward and Polly held hands as they made their way through the pines and firs to the cliff edge where the strange lights had been seen for three weeks running. The crazy-looking science guy on the news had said that similar lights had been observed in more than 11,000 locations worldwide; even the Halley VI research station in Antarctica had reported sightings over the Weddell Sea.

The city's edgelands were eerily quiet; most people had gravitated towards the built-up centres where the gathered multitudes offered a comforting, if false, glimmer of security. Others just stayed at home with loved ones to wait and hope and maybe pray that what was coming wasn't really coming.

As they trudged up the forest trail, Howard couldn't keep the thought out of his mind that he never again wanted to let go of this sweaty little hand. They were both out of breath when the track levelled off and gave way to a wide stretch of grass and then bare rock that led to the cliff's edge.

They stopped a few feet from the precipice. Howard kicked a small stone into the darkness but didn't hear it land. He could see across the ravine to the cliff on the opposite side. There were people there too, stick-like in the twilight distance. Maybe ten in all.

For weeks the talking heads on TV had been telling the world that no one knew what the cause of the increasingly strange phenomenon was, or what the outcome was likely to be, but deep down almost everyone had a bad, queasy feeling in their guts. And then last night they'd told it all, to the whole world, because what was the point in keeping it secret any more? The sightings had been increasing exponentially, and some lank-haired numbers-geek had worked out that if something was going to happen, it was going to happen tonight. And that something was going to be bad.

Howard took a hip flask from his jacket and unscrewed the cap. He offered Polly a

\section{$\rightarrow$ NATURE.COM}

Follow Futures:

y @NatureFutures

f go.nature.com/mtoodm drink and she made a funny face.

"Where the hell did you get that?" she asked.
"It was my Dad's. I never really knew what to do with it, but tonight seemed like as a good a night as any."

She took the flask and sniffed. "Do you even like whiskey?"

"Not really, but it'll be ... an experience! The sting of it sluicing down our throats, it'll

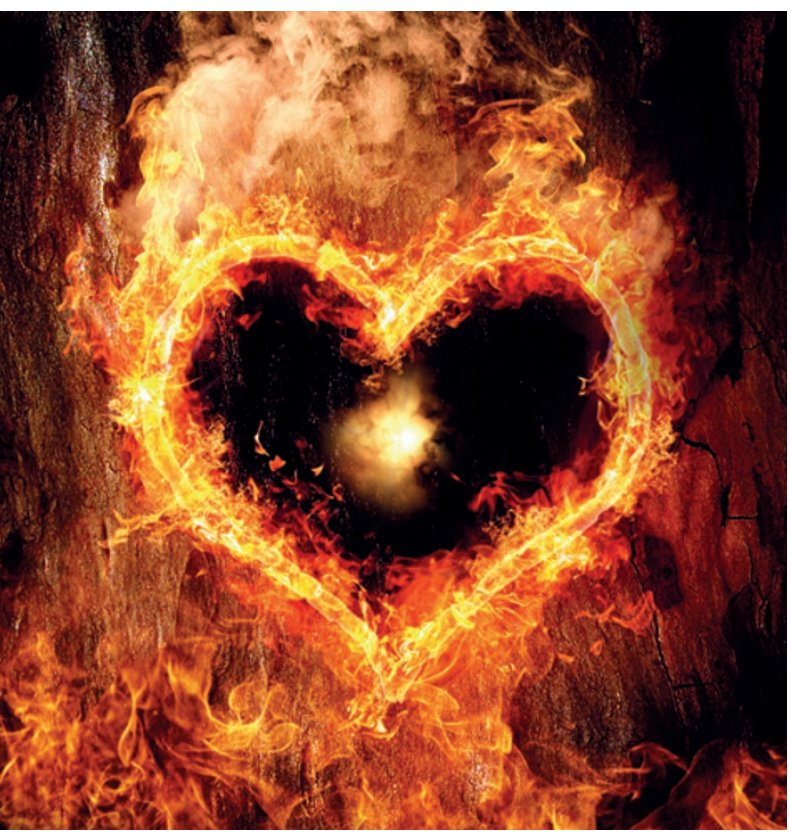

"Do you love me?" she asked. And he answered.

"Well, that is real, isn't it?" she said. And it was.

"We need to leave some mark. Something that will be here when we're not, something that will speak for us."

He rummaged in his pocket and pulled out a penknife. He clicked the large blade into place and walked to the largest fir tree he could see. "What's the plan, Stan?" Polly asked. Howard winked. She watched as he carved his name into the bark. And below it, hers. And between both crooked rows of letters he carved a misshapen, lopsided love-heart.

"There, that's real. That exists and will do when we are gone. I need it to. I need to know that some trace of what we feel will still be here in the morning."

"It will," Polly said. "Of course it will. We feel it don't we? Then it exists. I know you're not religious but, not everything dies when we do." And she said it so that she almost believed it.

"I just want ... I want whatever comes next to know that we were here. And that we felt the way we do. And that it was important to us."

They kissed, and the air above them

be real, won't it?"

Polly flashed a half-smile that made Howard's heart sing. She slugged and grimaced, and handed the flask back, coughing. Howard chuckled and took a deep swig. He felt the world spin a little as it hit the pit of his stomach. He stepped towards the edge and said: “Thanks, Dad. I miss you.” Pulling his arm back, he threw the silver flask as high and far as he could. It arced into the murky half-light of the ravine and disappeared.

"Yeah, that was real," Howard said. "But what does that even mean any more? This shouldn't be happening, not in the real world."

Polly shivered and Howard hugged her, he rubbed her arms and did his best to fight back the impotent fury that wanted to erupt and overwhelm him. They both did. They stifled their screams and did not beat their fists against the rocks. For they were better than that, here at the finish, better than the others who were coming to take what was not theirs. They would face the awful end in each other's arms, and on their own terms.

"I just... it's not real, is it? Is any of this real?" crackled and ruptured. Prying lights shone through the gaping wormhole in the sky, sickly yellow beams that seemed to come from somewhere beyond the physical world.

They walked to the edge of the cliff hand in hand.

And as the attack ships spilled through into unfamiliar skies, Howard and Polly held each other tight. They glanced back to their names carved on the tree - something real that would remain, they were sure of it. Sure of that much, at least.

They looked into each other's eyes as they let gravity take them over the edge, each holding on to the other, going on their own terms, which was better, and sure that someone, or something, would know how they had felt.

The cities fell.

And the trees burned.

And no one ever knew.

Martin Hayes can't write a love story without it turning into a mass-suicide, alien invasion terror-tale. Opinions as to what this may say about his psychological make-up can be sent to the author at www.paroneiria.com. 